\title{
ГОНЕНИЯ НА ГЕНЕТИКУ В РУССКОЙ ПРОЗЕ ВТОРОЙ ПОЛОВИНЫ ХХ ВЕКА
}

\author{
PRZEŚLADOWANIA GENETYKI W ROSYJSKIEJ PROZIE \\ DRUGIEJ POŁOWY XX WIEKU
}

\section{CAMPAIGN AGAINST GENETICS IN RUSSIAN LITERATURE IN THE SECOND HALF OF THE 20 ${ }^{\mathrm{TH}}$ CENTURY}

\author{
Наталья Попович \\ Российский православный университет Иоанна Богослова, Москва - Россия, \\ simba1da@yandex.ru
}

\begin{abstract}
Lysenkoism was a political campaign against genetics and science-based agriculture conducted by Trofim Lysenko, his followers and Soviet authorities. Many books on this theme were forbidden in Russia and published abroad. Novel The White Robes by Dudintsev is a fictionalized version of the devastation, which Lysenko wreaked on Soviet genetic study. Novels Nikolai Nikolaevich by Aleshkovsky and The Life and Extraordinary Adventures of Private Ivan Chonkin by Voinovich describe the topic in a satirical style. The actuality of the theme is confirmed by its presence in Russian mass media in the form of materials aimed at justifying Lysenko's activity in the recent years.
\end{abstract}

Ключевые слова: генетика, „лысенковщина”, Дудинцев, Алешковский, Войнович. Słowa kluczowe: genetyka, łysenkizm, Dudincew, Aleszkowski, Wojnowicz. Keywords: genetics, lysenkoism, Dudintsev, Aleshkovsky, Voinovich.

Лысенковщина - политическая кампания по преследованию и шельмованию группы генетиков, отрицанию генетики (вейсманизма-морганизма) и запрету генетических исследований в СССР. Кампания получила название по имени советского агронома и биолога Трофима Денисовича Лысенко, создателя мичуринской агробиологии, и разворачивалась с середины 1930-х по первую половину 1960-х гг. Ее организаторами были партийные деятели, в том числе Иосиф Виссарионович Сталин, представители марксистско-ленинской философии, деятели в области биологии. В книге советского ученого-биолога, профессора Владимира Яковлевича Александрова Трудные годы советской биологии. Записки современника названы причины разгрома генетики: это близость биологии к гуманитарным наукам, основой которых служила партийность, использование биологии в качестве фронта идеологической борьбы, проти- 
вопоставление советской биологии - „буржуазной лженауке"1. В 1930-е гг. стала явной необходимость срочных мер для восстановления сельского хозяйства, а открытия в биологии сулили быстрые результаты.

Лысенко организовал и возглавил силы, приведшие к разгрому биологии. Выходец из народа, молодой, инициативный ученый импонировал партийным деятелям. Лысенко рано понял, что может добиться положения руководителя науки. Для этого нужно было создать свою биологию и убедить власти в том, что она методологически единственно правильная, тогда как классическая биология методологически порочна, идеалистична, враждебна диалектическому материализму. В качестве знамени новой науки Лысенко удачно выбрал имя селекционера Ивана Владимировича Мичурина, автора более трехсот новых сортов растений. Так возникла „передовая советская мичуринская биология". Ее основные догмы: признание передачи по наследству приобретенных свойств, скачкообразного зарождения одного вида в недрах другого (Лысенко утверждал, что пшеница порождает рожь, капуста - брюкву; сосна - ель и т. д.), отрицание внутривидовой борьбы за существование. Мичуринская биология отрицала существование генов и отвергала положения современной биологии: законы наследственности Менделя; концепцию Августа Вейсмана об отсутствии наследования свойств, приобретенных в течение жизни; хромосомную теорию наследственности Томаса Моргана. Так была создана трехэтажная „ругательная" формула „менделизм-вейсманизм-морганизм”.

Лысенко выдвигал практические рекомендации для сельского хозяйства, и они внедрялись сразу на огромных площадях без предварительной проверки и учета местных условий. Широко известным примером таких нововведений стала тщетная работа над выведением сорта ветвистой пшеницы. Провалы маскировались фальсификацией данных и сглаживались очередным предложением, сулящим новые выгоды. Лысенко сделал невероятно стремительную карьеру: в 1938 г. он занимает место президента ВАСХНИЛ (Всероссийской академии сельскохозяйственных наук имени В. И. Ленина), сместив академика Николая Иваныча Вавилова, а после его ареста становится директором Института генетики АН СССР, трижды лауреатом Сталинской премии.

Ближайшими соратниками Лысенко стали академики Исаак Презент и Ольга Лепешинская. Презент - главный советник-методолог

1 В. Я. Александров, Трудные годы советской биологии. Записки современника, Санкт-Петербург 1993, с. 5-6. 
Лысенко по созданию теории мичуринской биологии и по уничтожению ее врагов и оппонентов. Лепешинская - автор теории о новообразовании клеток из бесструктурного „живого вещества”. Этим опровергался тезис немецкого ученого Рудольфа Вирхова о том, что клетка образуется только от клетки. Появился бранный термин „вирховианство”. В 1940-е гг. опубликован ряд „открытий”: клетки стали возникать из „кристаллов” плазмы крови, из сока алоэ, из сенного настоя, растительные клетки превращались в животные, животные в растительные и т. д. Лысенко воспользовался учением Лепешинской для объяснения своей теории зарождения одного вида „в теле” другого, и это направление стало одним из разделов мичуринской биологии.

Классическую генетику стали публично именовать „фашистской наукой", началось политическое преследование ученых: доносы, слежка, аресты, допросы и расстрелы (с конца 1930-х гг.). Трагически сложилась судьба академика Вавилова: он был арестован по подозрению в антисоветской деятельности в 1940 г., приговорен к смертной казни (позднее - к 15 годам лагерей) и умер в тюрьме в 1943 г. Более „мягкими” средствами являлись „проработки”, увольнения, исключения из партии, отмена кандидатских и докторских степеней. Многие ученые под страхом преследования изменили поле деятельности или присоединились к кампании против науки.

В то время наиболее массовой формой отступления ученых от нравственных норм был устный или письменный отказ от своих научных воззрений и одновременно признание мичуринских догм, лженаучность которых была очевидна²,

- пишет Александров. В рамках борьбы с космополитизмом блокировались контакты с зарубежными учеными, запрещалось участие в международных конференциях. Тем не менее многим ученым удалось избежать репрессий, и они продолжали заниматься генетическими исследованиями.

Роман Владимира Дмитриевича Дудинщева Белые одежды о жизни и работе ученых-биологов был издан в 1986 г., спустя тридцать лет с момента своего завершения, и отмечен Государственной премией СССР в 1988 г. Необычна история создания книги. Первый роман Дудинцева „Не хлебом единым” вызвал большой резонанс в литературной среде. Это книга об изобретателе, который во времена Сталина ведет тщетную борьбу с засильем начальства и бюрократией. Дудинцева подвергли „проработкам” и обвинили в иска-

2 Там же, с. 258-259. 
жении взаимоотношений власти и народа. Скандал вокруг книги сделал имя писателя известным, в том числе в научных кругах. К Дудинцеву стали обращаться ученые с просьбой написать о борьбе в биологической науке, они предоставили писателю множество материалов для работы над книгой. Таким образом, в книге отражены реальные события того времени.

Действие романа начинается в конце лета 1948 г., после знаменитой августовской сессии ВАСХНИЛ, ключевого события в противостоянии двух биологий, увенчавшегося победой „лысенковцев”. Следствием стала большая „кадровая чистка”: приказом министра образования Сергея Кафтанова более ста генетиков были уволены, их места заняли „лысенковцы”. Система преподавания биологии в СССР была разрушена: последовали смена программ, изъятие ряда учебников, составление новых мичуринских руководств. Работа и жизнь институтов находились под контролем правоохранительных органов, велось преследование преподавателей и студентов, занятых самостоятельным изучением биологии и верификацией насаждаемых сведений.

Многие герои романа имеют прототипов: „народный академик” Кассиан Дамианович Рядно - Лысенко, „левая рука" Рядно, Саул Брузжак - Исай Презент. Особый интерес вызывает образ главного героя - Федора Ивановича Дежкина. В начале книги он является соратником Рядно, его „правой рукой”. К академику герой питает почти сыновьи чувства, что, однако, не мешает ему бдительно наблюдать борьбу идей и внимать голосу разума и совести. Дежкин приезжает с ревизией в биологический институт, в котором когда-то учился. Изучая работы генетиков, он начинает понимать, что именно на стороне этих людей истина: его поражает их преданность науке, отвага, жертвенность, высокие моральные принципы. Дежкин от всего сердца начинает сочувствовать им, старается уберечь от расправы, а главное - не дать погибнуть их работе. В разгар гонений герой переходит на сторону „вейсманистов-морганистов", но, чтобы иметь возможность действовать, он вынужден прикрыть свои „белые одежды” маскхалатом.

Одним из прототипов Дежкина является академик Николай Васильевич Турбин, декан биофака МГУ. Имея репутацию единомышленника Лысенко, Турбин неожиданно для всех публикует в „Ботаническом журнале” статью Дарвинизм и новое учение о виде (1952, № 6) с разгромной критикой мичуринской биологии. Научная дискуссия в то время была невозможна, и появление в печати подобной работы означало прорыв цензурного запрета на критику, перелом в судьбе науки. Никогда не утихавшая борьба ученых 
против Лысенко смогла выйти из подполья. Этот эпизод воссоздан в романе. Еще одним прототипом Дежкина можно назвать профессора Александра Александровича Любищева, автора рукописи Монополия Лысенко В биологии, которую биолог отсылал в ЦК КПСС, в Министерство сельского хозяйства, в редакции центральных газет с целью возбудить проверку деятельности Лысенко. Подобные акты самопожертвования совершали многие настоящие ученые. Удивительным фактом является многолетняя переписка (с 1956 по 1971 г.) Любищева с инструктором отдела ЦК Владимиром Орловым, в которой ученый пытается переубедить партийного работника, озабоченного тяжелым состоянием сельского хозяйства, но искренне верящего в непогрешимость указаний партии. Если в начале переписки Орлов твердо отстаивает свои позиции, то в дальнейшем он явно поддается влиянию логики, аргументации Любищева. Тон писем был взаимно уважительным, и Орлов неоднократно обращался к Любищеву как к своему учителю. Материалы переписки была опубликованы в 1988 г. в новосибирском журнале „ЭКО” (№ 2, 3) под названием Неприлично молчание мне... (цитата из письма Любищева). Подобный эпизод есть в романе: „Учителем” Дежкина называет полковник НКВД Свешников, старый большевик, идущий на отчаянный риск с целью помочь генетикам, отдавший жизнь во имя победы справедливости и добра.

Система образов романа строится на антитезе: герои делятся на защитников настоящей науки, тех, кто носит „белые одежды”, и их противников, гонителей. Множество героев по ходу событий делают выбор, переходят на другую сторону. К генетикам приходят Дежкин, академик Посошков, когда-то публично покаявшийся в „вейсманизме-морганизме”, селекционер-садовод Цвях, студентка Женя Бабич; в стан „лысенковцев переметнулась аспирантка Анжела Шамкова, сделавшая публичный донос на своего учителя, выбор в пользу карьеры и денег делает Краснов, тайный соглядатай Рядно.

Белые одежды - роман социально-философский. Политическая атмосфера 40-50-х годов является фоном для исследования вечного противоборства Добра и Зла. Поставленная писателем проблема - нравственный выбор человека, поиск истины. Эпиграф книги взят из „Апокалипсиса” Иоанна Богослова, в романе эти строки цитирует Цвях: „Сии, облеченные в белые одежды, Кто они и откуда пришли?... Они пришли от великой скорби"з. Белые одежды - символ истины, добра, света. В скорби сердца, в муках совести рожда-

\footnotetext{
${ }^{3}$ В. Н. Дудинцев, Белые одежды, Санкт-Петербург 2013, с. 50.
} 
ется у главного героя тезис „Добро - это страдание"4. Образ Ивана Ильича Стригалева - собирательный образ ученых, пострадавших во время гонений. Долгом чести становится для Дежкина продолжение работы Стригалева по выведению нового сорта картошки, он становится двойником погибшего в тюрьме ученого, принимает на себя испытания, выпавшие на долю защитников науки. Слова Стригалева становятся своеобразным гимном истинных ученых:

Ночь, покров для злых намерений и дел, пусть будет теперь убежищем добру. Потому как что мы хотим сделать людям? Страдание? Учитель, отвечайте! Радость, радость мы хотим дать людям! Чудесные сорта! Убрать бревно с дороги! Избавить от страха и ненужных забот5.

Помимо белых одежд в романе еще множество символов: спящая почка, железная труба, троллейбус, песочные часы, парашютист. Образы Гамлета, Святого Себастьяна, Торквемады включают книгу в широкое культурное пространство, развивают и подчеркивают актуальность вечных вопросов, которыми задаются герои.

Эпизод, связанный с учением Лысенко, есть в романе-анекдоте Владимира Николаевича Войновича Жизнь и необычайные приключения солдата Ивана Чонкина (1963-1969, опубликован за границей в 1975 г., на родине - в 1988 г.). Селекционер-любитель Кузьма Гладышев, состоящий в должности колхозного кладовщика, почитается односельчанами за человека крайне образованного:

Об учености Гладышева говорил хотя бы тот факт, что на деревянной уборной, стоявшей у него в огороде, большими черными буквами было написано „Water closet” 6 .

Благодаря Октябрьской революции, „которая освободила народ от всевозможного рабства и любому гражданину позволила карабкаться к сияющим и каменистым вершинам науки"7, Гладышев задумал обессмертить свое имя в науке, а именно:

вдохновленный прогрессивным учением Мичурина и Лысенко, надумал он создать гибрид картофеля с помидором, то есть такое растение, у которого внизу росли бы клубни картофеля, а наверху одновременно вызревали бы помидоры. Будущий свой гибрид Гладышев назвал в духе того великого времени „Путь к социализму”, или сокращенно „ПУКС"8.

4 Там же, с. 46.

5 Там же, с. 197.

${ }^{6}$ В.Н. Войнович, Жизнь и необычайные приключения солдата Ивана Чонкина, [в:] его же, Малое собрание сочинений в 5-ти томах, т. 2, Москва 1993, с. 49.

7 Там же.

8 Там же, с. 50. 
В названии гибрида писателем остроумно обыграно пристрастие советской власти к новоязу.

Стремления Гладышева отражают восприятие научных исследований „самородками” из деревни, имеющих за плечами, как и сам герой, два класса церковно-приходской школы.

Лысенко, руководствуясь тезисом „науку может двигать вперед и простой колхозник", привлек к своей деятельности большое число полуграмотных людей, не имеющих представления о требованиях, которые ставит исследовательская работа перед учеными',

- пишет Александров. Понятия строгого контроля, чистоты опыта, достаточной повторности, статистической достоверности таким горе-исследователям были незнакомы. Основным условием для получения нужных результатов, как указывал Лысенко, была вера в них. Это очень облегчало работу.

Несмотря на отсутствие результатов, начинающего селекционера кто-то „заметил и поддержал, чего не могло быть в проклятое царское время"10. Для подтверждения успехов сельского хозяйства требовались все новые факты - о выведении ПУКСА напечатали в газете „Большевистские темпы”. И хотя в отзыве академика опыты Гладышева были названы „антинаучными и бесперспективными" 11 , ученый, очевидно, вынужден был учитывать обстановку в науке. Поэтому

он советовал Гладышеву не падать духом и, ссылаясь на пример древних алхимиков, утверждал, что в науке никакой труд не бывает напрасным, можно искать одно, а найти другое. И письмо это, несмотря на его смысл, произвело на адресата сильное впечатление, тем более, что напечатано было на официальном бланке солидного учреждения, где Гладышева называли „уважаемый товарищ Гладышев” и где академик собственноручно поставил подпись. И на всех, кто читал письмо, это тоже производило известное впечатление ${ }^{12}$.

Таким образом, писатель воссоздает механизм проникновения в науку псевдонаучных теорий. Самая сомнительная идея, подтвержденная документально газетными публикациями, отзывами специалистов крепла и становилась самостоятельной. Чтобы ее опровергнуть, требовались уже немалые усилия.

К теме фикций советского времени можно отнести пародию писателя на „стахановское движение”, названное „движение мяки-

9 В. Я. Александров, указ. соч., с. 11.

10 В. Н. Войнович, указ. соч., с. 50.

11 Там же, с. 51.

12 Там же. 
шевок". Передовики производства участвовали в соцсоревнованиях по всей стране и давали действительно рекордные показатели. Однако среди энтузиастов оказалось немало имитаторов. Мякишевки давали обязательства и пользовались почетом при полном отсутствии достижений. Люшка Мякишева стала известной дояркой-передовичкой, сделала карьеру в высших сферах благодаря газетной шумихе вокруг ее нового метода доения коров:

Выступая в Кремле на съезде колхозников, Люшка заверила собравшихся и лично товарища Сталина, что с отсталой прежней технологией покончено отныне и навсегда. А на реплику товарища Сталина: Кадры! Кадры! обязалась обучить своему методу всех доярок своего колхоза ${ }^{13}$.

С тех самых пор не видели Люшку в колхозе: то она выступает, то заседает, то получает премии, то дает интервью.

Совсем замоталась Люшка. Прискачет на день-другой в родную деревню, подергает корову за соски перед фотоаппаратом и дальше... Коров доить стало совсем некому14,

- подводит итоги писатель. Сатирическое изображение советской действительности стало причиной вынужденной эмиграции Войновича в 1980 г., в 1981 г. указом Леонида Брежнева писатель был лишен советского гражданства.

Повесть Ю. Алешковского Николай Николаевич (написана 1970 г., издана в 1980 г.) имеет подзаголовок: Светлое путешествие в мрачном гадюшнике советской биологии ${ }^{15}$. Писатель использует сказ - повествование от лица молодого вора-карманника, который после освобождения из лагеря работает в биологическом институте донором спермы. Главный герой повести Николай - „простой человек”, народный нонконформист, не питающий иллюзий насчет сущности государственной системы. Несмотря на отсутствие у героя образования, тюремные замашки и нежелание работать, рисуется в целом привлекательный образ человека по-своему неглупого, смелого, помнящего добро, готового помочь. Пребывание в лагере не сломили Николая, наоборот, закалили характер, придали веру в себя. Такой герой является носителем правды о жизни: его не обольщают высокопарные слова и лозунги и не пугают угрозы представителей власти.

13 Там же, с. 121.

14 Там же, с. 122.

15 Ю. Алешковский, Николай Николаевич, [в:] его же, Малое собрание сочинений в 3-х томах, т. 1, Москва 1993, с. 3. 
Биологический институт переживает время торжества лысенковской псевдонауки. Описана атмосфера страха и подозрительности: доносы сотрудников друг на друга, слежка, поиск вредителей. Академик говорит герою: „А времена знаете какие? Мы - генетики - без пяти минут враги народа. Да-с"16. Наблюдая обстановку, герой приходит к выводу о том, что

...интеллект - дело наживное, если он вообще человеку нужен... Ты бы посмотрел, как ученые хавают друг друга без соли, б..., в сыром виде, разве что пуговички сплевывают ${ }^{17}$.

Противопоставление научного института исправительному заведению дает сатирический эффект: „Учреждение ваше - НИИ - склочное, и порядка в нем нету. Не то что в тюрьме или в БУРе"18, - говорит Николай. БУР на лагерном жаргоне означает „барак усиленного режима", лагерную тюрьму. В восприятии героя тюремная дисциплина воспринимается как неоспоримое достижение и превосходит „беспредел” жизни на воле.

Лаборатория Кимзы, где работает герой, занимается сексологией, ставит эксперименты, в частности решает проблему бесплодия путем искусственного оплодотворения. В самом названии повести Николай Николаевич гипотетически подразумевается потомство главного героя. По словам писателя, идея донорства спермы в то время была чисто фантастической, и он не подозревал о том, что подобными исследованиями займется мировая наука. Впечатляет в прямом смысле космический масштаб перспектив работы лаборатории:

Кимза мечтал запустить мою малофейку на Андромеду... и посмотреть, что выйдет... они бы попали на Андромеду и в стеклянном приборе, как в пузе, забеременели бы. Через девять месяцев - раз, и появляются на планете Андромеда живехонькие Николаи Николаичи! Штук сто сразу, и приспосабливаются... к окружающей среде. Не веришь? ${ }^{19}$

- с гордостью говорит герой. В этом эпизоде дана ироническая отсылка писателя к научно-фантастическим романам, столь популярным в СССР.

Вы, батенька, возможно будете прародителем вновь зарождающегося человеческого племени на другой планете! Каждый ваш живчик пойдет в дело!

\footnotetext{
16 Ю. Алешковский, указ. соч., с. 15.

17 Там же, с. 16.

18 Там же, с. 12.

19 Там же, с. 15
} 
В одном термосе - народ, в двух - нация! А может, наоборот. Сам черт не разберется в этих сталинских формулировках ${ }^{20}$,

- говорит Николаю академик. Излюбленный прием писателя - пародийно снижающий перифраз советских лозунгов, комический эффект достигается благодаря включению цитаты в низкий, бытовой контекст.

В повести есть упоминание о работе лаборатории Лепешинской, в частности высмеяна теория самозарождения клеток. Карманник Николай верит в народную примету: зубовный скрип вызывает появление глистов. Академик, слыша это заявление, приходит в возбуждение:

Подкиньте эту идею Лепешинской, пусть ее молодчики скрипят зубами и ждут самозарождения глистов в своих прямых кишках. По теории вероятности успех обеспечен. А еще лучше - вставьте им в анусы по зубному протезу... Шарлатаны! Варвары! Нахлебники! Враги народа!21

При разгроме лаборатории „замдиректора еще чего-то читал про вредительство в биологической науке и как Лысенко их разоблачил, насчет империализма-менделизма и космополитизма..." 22. Автор использует прием „взгляд наивного героя":

С ходу решаю уйти в глухую несознанку. С Менделем я не знаком, на очной ставке так и скажу... А насчет морганизма прокурору по надзору скажу прямо, что моей ноги в морге не было и не будет... Чего-чего, а морганизма, сволочи, не пришьете. За него больше дают, чем за живое изнасилование 23 .

Писатель обыгрывает восприятие формулы „менделисты-морганисты" простым героем. Разумеется, Николаю неизвестно имя ученого монаха Менделя, основоположника учения о наследственности, позже названного по его имени менделизмом. Комизм ситуации заключается в том, что Мендель, умерший в конце XIX века, не может явиться на очную ставку с героем. По народной этимологии термин „морганизм” герой объясняет связью с моргом, прилегающим к институту. Морганизм в понимании Николая должен означать, очевидно, то же, что и некрофилия - влечение к трупам.

Следует подчеркнуть двойственное отношение Алешковского к науке: с одной стороны, это сатира на засилие в науке „лысенковцев", с другой - скептическое отношение к бессмысленным экспе-

\footnotetext{
20 Там же.

21 Там же, с. 16.

22 Там же, с. 24.

23 Там же.
} 
риментам, бесполезной работе, которая требует непомерных затрат. Подопытный Николай становится практически инвалидом: „Мне весь череп истыкали, все клетку мозга искали, которая исключительно еблей распоряжается..." 24. В финале повести герой решительно отказывается от участия в экспериментах, решает сменить род занятий и стать сапожником. Старый академик является выразителем авторской позиции. Подводя итоги своей жизни, он говорит:

Я считаю, что не зря жил и трудился в науке. Мне, слава Богу, стала окончательна непонятна тайна жизни, и я уверен: никто ее не поймет!... Ради понимания этого стоило жить все эти страшные годы ${ }^{25}$.

Десятилетия монополии Лысенко нанесли непоправимый вред не только биологической науке, но и престижу страны. История разгрома генетики была запечатлена в многочисленных документах, отражена в мемуарной, публицистической и художественной литературе. Даже после ухода Лысенко книги, рассказывающие правду о войне в биологии, были долгое время под запретом. Реальные события отражены в романе Дудинцева Белые одежды. В сатирическом ключе лысенковская псевдонаука представлена в произведениях Войновича и Алешковского. Споры вокруг гонений на генетику не утихают до сих пор: в последние годы в российских СМИ появился ряд материалов с целью оправдать деятельность Лысенко и его сторонников ${ }^{26}$. Это связано, очевидно, с реконструкцией мифа об советской стране, ностальгией по СССР. Художественное наследие русской литературы второй половины XX века поможет современному читателю сформировать свое мнение, чтобы избежать повторения ошибок прошлого.

\section{Библиография}

Александров В.Я., Трудные годы советской биологии. Записки современника, Санкт-Петербург 1993.

Алешковский Ю., Николай Николаевич, [в:] его же, Малое собрание сочинений в 3-х томах, т. 1, Москва 1993.

${ }^{24}$ Ю. Алешковский, указ. соч., с. 40.

${ }^{25}$ Там же, с. 48.

${ }^{26}$ См. например: С. Миронин, Кто такой Лысенко и почему его поливают грязью, [в:] электронный ресурс: http://www.rusproject.org/pages/analysis/analysis_10/lisenko_ miron.html (26.12.15); Н. Овчинников, Дискуссии между мичуринцами и вейсманистами, [в:] электронный ресурс: http://stalinism.ru/elektronnaya-biblioteka/akademik-trofimdenisovich-lyisenko.html?showall=\&start=8 (26.12.15). 
Войнович В. Н., Жизнъ и необычайные приключения солдата Ивана Чонкина, [в:] его же, Малое собрание сочинений 8 5-ти томах, т. 2, Москва 1993.

Дудинцев В.Н., Белые одежды, Санкт-Петербург 2013.

Миронин С., Кто такой Лысенко и почему его поливают грязью, [в:] электронный ресурс: http://www.rusproject.org/pages/analysis/analysis_10/lisenko_miron.html (26.12.15).

Овчинников Н., Дискуссии между мичуринцами и веисманистами, [в:] электронный pecypc: http://stalinism.ru/elektronnaya-biblioteka/akademik-trofim-denisovichlyisenko.html? showall=\&start=8 (26.12.15). 